Revista Brasileira de Farmacognosia Brazilian Journal of Pharmacognosy 22(1): 162-168, Jan./Feb. 2012

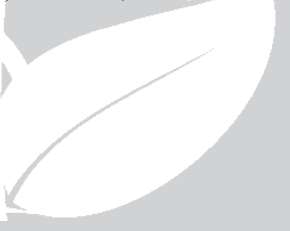

Article

Received 25 Jan 2011

Accepted 1 Aug 2011

Available online 21 Nov 2011

Keywords:

anti-inflammatory

antinociceptive

Bignoniaceae

Pyrostegia venusta

ISSN 0102-695X

http://dx.doi.org/10.1590/S0102-

695X2011005000209

\section{Anti-inflammatory and antinociceptive effects of the hydroethanolic extract of the flowers of Pyrostegia venusta in mice}

\author{
Clarice C. Veloso, ${ }^{1}$ Layla D. M. Cabral, ${ }^{1}$ Andressa D. Bitencourt, ${ }^{1}$ \\ Lidiane S. Franqui, ${ }^{1}$ Flávia V. Santa-Cecília, ${ }^{2}$ Danielle F. Dias, ${ }^{2}$ \\ Roseli Soncini, ${ }^{1}$ Fabiana C. Vilela, ${ }^{1}$ Alexandre Giusti-Paiva ${ }^{*}, 1$
}

\author{
${ }^{1}$ Laboratório de Ciências Fisiológicas, Instituto de Ciências Biomédicas, \\ Universidade Federal de Alfenas, Brazil, \\ ${ }^{2}$ Faculdade de Ciências Farmaceuticas, Universidade Federal de Alfenas, Brazil.
}

\begin{abstract}
Pyrostegia venusta (Ker Gawl.) Miers, Bignoniaceae, is native to the Brazilian Cerrado and popularly known as “cipó-de-são-joão”. In Brazilian folk medicine, the flowers of $P$. venusta are used as a general tonic and a treatment for diarrhea, vitiligo, cough, and common infections and inflammatory diseases of the respiratory system. Nevertheless, there are still no studies on its possible anti-inflammatory and antinociceptive effects. The $P$. venusta hydroethanolic extract (PvHE) was used to evaluate the anti-inflammatory and analgesic effects in carrageenan-induced paw edema, peritonitis induced by lipopolysaccharide, acetic acid-induced writhing, and formalin-induced paw-licking tests in Swiss male mice. PvHE at doses of 30-300 mg/kg p.o. demonstrated anti-inflammatory effect. PvHE reduced paw edema induced by carrageenan and inhibited leukocyte recruitment into the peritoneal cavity. The extracts showed antinociceptive activity in acetic acid-induced writhing and formalin tests. Our results showed that the PvHE demonstrated anti-inflammatory and antinociceptive action in mice. All the anti-inflammatory actions obtained are also suggested to due the presence of acacetin-7-O- $\beta$-glucopyranoside.
\end{abstract}

\section{Introduction}

Many species belonging to the Bignoniaceae family, such as Pyrostegia venusta (Ker Gawl.) Miers are known to be of medicinal value (Emmanuel et al., 2010). P. venusta is popularly known in Brazil as "cipóde-são-joão", "cipó-caititu", "cipó-tingá" and "dedode-moça" (Pool, 2008) and is widely distributed in the cerrado, which is noted as being a typical ecosystem of central and southeastern Brazil (Blatt et al., 1998). In folk medicine, the aerial parts of $P$. venusta are mainly used as an infusion or decoction. They are administered orally as a general tonic for the treatment of diarrhea, vitiligo, cough and common infections and inflammatory diseases of the respiratory system, such as bronchitis, flu and the common cold (Ferreira et al., 2000; Scalon et al., 2008; Cardozo et al., 2009). Previous studies demonstrated that the hydroethanolic extract of flowers of $P$. venusta attenuated the sickness behavior induced by lipopolysaccharide (LPS) in the forced swim and open field test, suggesting that the extract inhibits immune and inflammatory responses, including cytokine and prostaglandin production, supporting the popular use of $P$. venusta as a general tonic as well as a treatment for the general symptoms of flu and cold (Veloso et al., 2010).

The literature records the phytochemical study of the flowers of $P$. venusta, from which the compounds $\beta$-sitosterol, $n$-hentriacontane, acacetin-7-O$\beta$-glucopyranoside and meso-inositol have been isolated (Dubey \& Misra, 1976; Veloso et al., 2010). Other studies have indicated the presence of carotenoids in the flowers (Harborne, 1967) and rutin in the leaves (Blatt et al., 1998). It has been demonstrated that the compounds acacetin-7-O- $\beta$-glucopyranoside and $\beta$-sitosterol showed anti-inflammatory activity (Gupta et al., 1980; Shen et al., 2010).

Due to the large variety of compounds found in the flowers of this species and a need to effectively identify anti-inflammatory and analgesic therapies, the objective of this study was to evaluate the anti-inflammatory and analgesic effects of the hydroethanolic extract of $P$. venusta flowers in animal models.

\section{Material and Methods}




\section{Plant material}

Pyrostegia venusta (Ker Gawl.) Miers, Bignoniaceae, were collected in Alfenas, Minas Gerais, Brazil. The plant was identified by Dr. G. Alves-daSilva from the Department of Pharmacy at the Federal University of Alfenas, and the voucher specimen (699) has been deposited at the Herbarium of the Federal University of Alfenas-MG.

\section{Preparation of the plant extracts and reference drugs}

The flowers of $P$. venusta were dried in an oven at $40{ }^{\circ} \mathrm{C}$ and powdered. The $P$. venusta hydroethanolic extract (PvHE) was obtained by maceration in a $50 \%$ hydro-alcoholic solution for $48 \mathrm{~h}$ at room temperature, and this procedure was repeated twice. The PvHE was concentrated on a rotary evaporator and then dried with a spray dryer (Büchi Mini Spray Dryer B-290). The yield of the PvHE was $6.0 \%$.

The PvHE were administered in 30,100 , and $300 \mathrm{mg} / \mathrm{kg}$ doses after being suspended in a vehicle (1\% sodium carboxymethylcellulose suspension in distilled water). Dexamethasone $(1 \mathrm{mg} / \mathrm{kg})$ and morphine sulphate $(10 \mathrm{mg} / \mathrm{kg})$ was diluted in sterile saline $(0.9 \%$ $\mathrm{NaCl})$. Indomethacin $(10 \mathrm{mg} / \mathrm{kg})$ was diluted in Tris buffer $(\mathrm{pH}$ 8.5). The animals in the control group received the same experimental handling as those in the test groups, with the exception that the drug treatment was replaced with appropriate volumes of the dosing vehicle. Dexamethasone, indomethacin and morphine sulphate were used as reference drugs. All test drugs were intraperitoneally administered, except for indomethacin, which was orally administered.

Determination of the total phenolics and flavonoids in the PvHE

The total phenolic content in the PvHE was determined using the Folin-Ciocalteu methods, and the total flavonoid content was determined according to previous described (Singleton et al., 1999).

\section{Pharmacological procedures}

\section{Animals}

Adult male Swiss mice (22-28 g) were obtained from the Central Animal Facility of the Federal University of Alfenas and housed under controlled light $(12: 12 \mathrm{~h}$ light:dark cycle; lights on at 6:00 am) and temperature conditions $\left(23 \pm 1{ }^{\circ} \mathrm{C}\right)$ with access to water and food ad libitum. The animals were allowed to habituate to the housing facilities for at least one week before the experiments were started. All experiments were conducted according to Brazilian Regulations for animal experimentation (COBEA), after approval by the Ethical Commission of Animal Experimentation at the Federal University of Alfenas (\#269/2009). The doses used in the present study were selected based on previous studies (de Paiva et al., 2010; Vilela et al., 2010).

\section{Evaluation of anti-inflammatory activity in mice}

\section{Carrageenan-induced mice paw edema}

Paw edema was measured with a plethysmometer (Model 7140, Ugo Basile, Italy). The basal volume of the right hind paw was determined before the administration of any drug. After determination of the basal volume, the animals ( $\mathrm{n}=8$ per group) were divided into the experimental groups in such a way that the mean volumes of the different groups were similar. The vehicle, PvHE or indomethacin was orally administered $1 \mathrm{~h}$ before i.pl. injection of carrageenan $(1 \mathrm{mg} / \mathrm{paw}, 20 \mu \mathrm{L})$. The paw volume was measured at $1,2,3$ and $4 \mathrm{~h}$ after injection of the inflammatory stimulus. The results are presented as the paw volume $(\mathrm{mL})$ variation in relation to the basal values.

\section{Peritonitis induced by lipopolysaccharide}

To assess the possible effect of the PvHE on leukocyte recruitment into the peritoneal cavity, the animals ( $\mathrm{n}=8$ per group) were orally pre-treated with the vehicle and PvHE and intraperitoneally administered with dexamethasone. Thirty minutes later, lipopolysaccharide (LPS) from Escherichia coli 026:B6 (100 $\mu \mathrm{g} / \mathrm{kg}$ i.p.) dissolved in pyrogen-free sterile saline was administered. Four hours after the injection of LPS, the mice were killed by an inhalatory overdose of halothane, and the cells from the peritoneal cavities were harvested by injecting $5.0 \mathrm{~mL}$ of PBS containing $0.5 \%$ of sodium citrate. The abdomens were gently massaged and the blood-free cell suspension was carefully aspirated with a syringe. Abdominal washings were placed into plastic tubes, and total cell counts were performed in a Neubauer chamber (Cunha et al., 1989; Vilela et al., 2010).

\section{Evaluation of antinociceptive activity in mice}

\section{Acetic acid-induced writhing in mice}

Acetic acid $(0.6 \% \mathrm{v} / \mathrm{v}, 10 \mathrm{~mL} / \mathrm{kg})$ was injected into the peritoneal cavities of mice, which were placed in a large glass cylinder, and the intensity of the nociceptive behavior was quantified by counting the 
total number of writhes occurring between 0 and 20 min after the stimulus injection, as described earlier by Koster et al., (1959). Oral treatments with the vehicle, indomethacin or the PvHE, were given $1 \mathrm{~h}$ prior to the acetic acid injection ( $\mathrm{n}=6$ per group). The writhing response consists of a contraction of the abdominal muscle together with a stretching of the hind limbs. The antinociceptive activity was expressed as writhing scores over a period of $20 \mathrm{~min}$.

\section{Formalin-induced nociception}

A formalin solution $(5 \%$ in $0.9 \%$ saline; 20 $\mu \mathrm{L} /$ paw) was injected into the hind paw plantar surface (i.pl.), and the animals were individually placed in transparent observation chambers, as previously described (Santos \& Calixto, 1997). Oral treatments (p.o.) with the vehicle, indomethacin or the PvHE were given $1 \mathrm{~h}$ prior to formalin injection ( $\mathrm{n}=8$ per group). Morphine was administrated (i.p.) $30 \mathrm{~min}$ before the test. The time spent in licking the injected paw was recorded and expressed as the total licking time in the early phase (0-5 min) and late phase (20-30 min) after formalin injection.

\section{Open-field test}

To discard the possible nonspecific muscle relaxants or the sedative effects of the extract, the motor performance of the mice was evaluated on the open-field apparatus (Archer, 1973). Groups of mice $(n=10)$ were treated with the vehicle or PvHE one hour before the test. Each animal was placed in the center of the openfield arena and allowed to have free ambulation for 5 min for the observation of the locomotion frequency (number of floor units the animal entered on all its limbs).

Evaluation of acute toxicity of the Pyrostegia venusta extract

The PvHE $(0.5-5 \mathrm{~g} / \mathrm{kg})$ was orally administered to a group of mice, both male and female. The behavior parameters observed after administration were convulsion, hyperactivity, sedation, grooming, and increased or decreased respiration during a period of seven days. Food and water were provided ad libitum.

\section{Statistical analysis}

The data obtained were analyzed using the GraphPad software program v.4.0 and expressed as mean \pm SEM Statistically significant differences between the groups were calculated by the application of an analysis of variance (ANOVA), followed by the Newman-Keuls test $(p<0.05$ were considered significant).

\section{Results}

\section{Total phenols and flavonoids contents}

The analysis showed that the level of polyphenolics compounds in the PvHE was $998 \mathrm{mg} / \mathrm{g}$ extract. The content of total flavonoids was $543 \mathrm{mg}$ quercetin equivalent/g extract. Our previous reports showed that a principal constituent was identified as the flavonoid acacetin-7-O-glycopyranoside by HPLC/ DAD analysis (Veloso et al., 2010).

\section{Carrageenan-induced mice paw edema}

Figure 1 shows that the PvHE significantly inhibited $\left(\mathrm{F}_{435}=6.12 ; p=0.0009\right)$ the carrageenaninduced mice paw edema at doses of $30-300 \mathrm{mg} / \mathrm{kg}$ at 3 $\mathrm{h}$ post carrageenan, with inhibitions of $56.5 \%, 74.78 \%$ and $89.13 \%$, for 30,100 and $300 \mathrm{mg} / \mathrm{kg}$, respectively. Indomethacin $(10 \mathrm{mg} / \mathrm{kg})$ gave a percentage inhibition of $73.48 \%$.

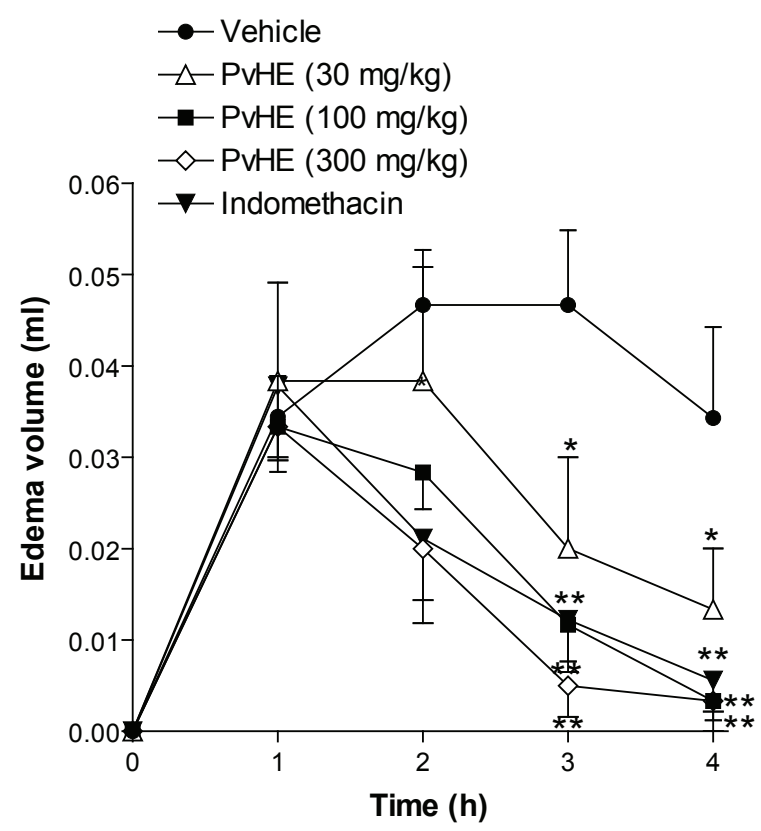

Figure 1. Effects of the administration of the hydroethanolic extract of Pyrostegia venusta flowers (PvHE; 30, 100 and 300 $\mathrm{mg} / \mathrm{kg}$, p.o.) or indomethacin $(10 \mathrm{mg} / \mathrm{kg}$, p.o.) on mice paw edema induced by intraplantar (i.pl.) carrageenan injection (1 $\mathrm{mg} / \mathrm{paw})$. Each point represents the mean $\pm \mathrm{SEM}$ of eight animals. The asterisks denote the significance levels when compared with the control group: ${ }^{*} p<0.05,{ }^{*} p<0.01$. 


\section{Peritonitis induced by lipopolysaccharide}

In agreement with previous studies, LPS-induced peritonitis was followed by a significant increase in the number of leukocytes in the peritoneal cavity of mice when compared to the control group treated only with the vehicle (Vilela et al., 2010). The PvHE (30-300 mg/ $\mathrm{kg})$ significantly inhibited $\left(\mathrm{F}_{5,35}=8.29 ; p<0.001\right.$; Figure 2$)$ leukocyte recruitment induced by LPS $(100 \mu \mathrm{g} / \mathrm{kg})$ into the peritoneal cavity in mice at doses of $30-300 \mathrm{mg} / \mathrm{kg}$. The inhibition of leukocyte recruitment at $4 \mathrm{~h}$ post-LPS were $51.7 \%, 87.3 \%$ and $95.2 \%$ for 30,100 and $300 \mathrm{mg} /$ $\mathrm{kg}$, respectively. Dexamethasone $(1 \mathrm{mg} / \mathrm{kg})$ showed an inhibition $(\mathrm{p}<0.001)$ of $98.9 \%$.

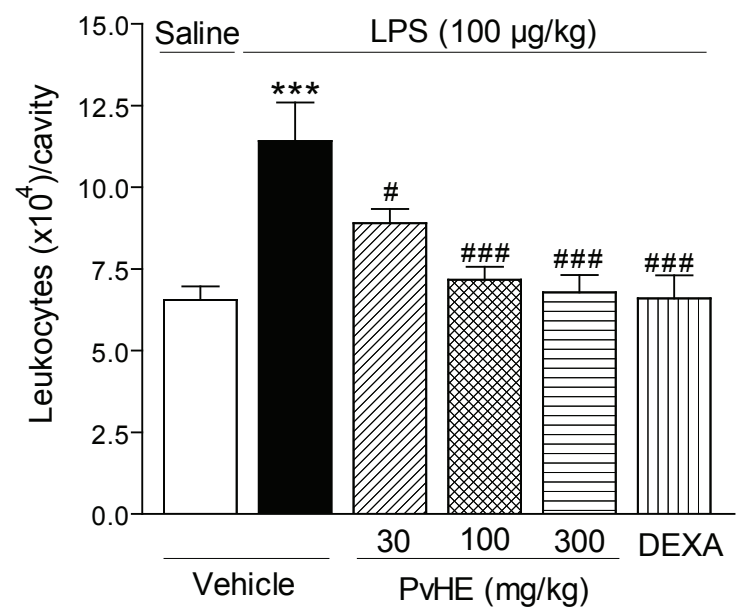

Figure 2. Effects of the administration of the hydroethanolic extract of Pyrostegia venusta flowers (PvHE; 30, 100 and $300 \mathrm{mg} / \mathrm{kg}$, p.o.) or dexamethasone (DEXA, $1 \mathrm{mg} / \mathrm{kg}$, i.p.) on the lipopolysaccharide-induced recruitment of leukocytes to the peritoneal cavity of mice. Each column represents the mean \pm SEM of six animals. $* * * p<0.001$ compared with the saline+vehicle group. $\# p<0.05$; \#\#\#p<0.01 compared with LPS+vehicle group.

\section{Acetic acid-induced writhing in mice}

Figure 3 shows the results of the acetic acid writhing test. The PvHE at doses of 100 and $300 \mathrm{mg} / \mathrm{kg}$ significantly reduced $\left(\mathrm{F}_{4,42}=7.67 ; p<0.001\right)$ the number of writhes by $43.20 \%$ and $69.10 \%$, respectively. Indomethacin at a dose of $10 \mathrm{mg} / \mathrm{kg}$ exhibited a significant percentage reduction $(p<0.001)$ in acetic acid-induced writhing of $65.32 \%$.

\section{Formalin test in mice}

The PvHE at doses of $30-300 \mathrm{mg} / \mathrm{kg}$ p.o. produced a significant antinociceptive activity compared to the control, reducing formalin-induced nociceptive responses during the first $\left(\mathrm{F}_{5,57}=6.14 ; p<0.001\right.$; Figure 4A) and second $\left(\mathrm{F}_{557}=7.90 ; p<0.001\right.$; Figure 4B) phases. The reference drug indomethacin suppressed only the second phase of the formalin test, whereas morphine inhibited both phases of the pain stimulus.

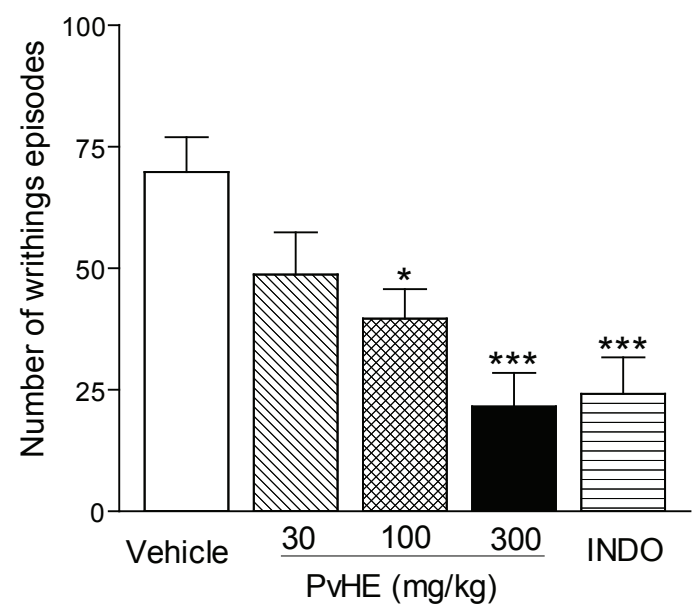

Figure 3. Effects of the hydroethanolic extract from Pyrostegia venusta flowers (PvHE) administered orally against acetic acid-induced writhing movements in mice. Animals were pretreated orally with the vehicle, PvHE (30, 100 , and $300 \mathrm{mg} / \mathrm{kg}$ ), and indomethacin (INDO, $10 \mathrm{mg} / \mathrm{kg}$ ) prior to the acetic acid $(0.6 \%$, i.p. $)$. Each column represents the mean with SEM for eight mice. The asterisks denote the significance levels when compared with the control group: ${ }^{*} p<0.05 ; * * * p<0.001$.

\section{Open-field test}

Mice treated with the PvHE at $30-300 \mathrm{mg} / \mathrm{kg}$ did not display a reduction in the numbers of crossings and rearings when compared to the control group in the open-field test (data not shown).

\section{Acute toxicity}

The PvHE given to mice at a dose of $0.5-5$ $\mathrm{g} / \mathrm{kg}$ p.o. had no affect on their behavioral responses during the observation period of seven days after administration. No mortality was observed up to seven days of monitoring. The estimated LD50 value of these extracts in mice was therefore more than $5 \mathrm{~g} / \mathrm{kg}$ p.o. Because the effective dose used in the present study $(100 \mathrm{mg} / \mathrm{kg}$ p.o. $)$ was 5 -fold less than the dose used in the acute toxicity test, we assume that the doses of 30 , 100 , and $300 \mathrm{mg} / \mathrm{kg}$ p.o. given to mice in this study were safe.

\section{Discussion}

The flowers of Pyrostegia venusta (Ker Gawl.) Miers, Bignoniaceae, are commonly used in 
traditional Brazilian medicine for the treatment of various inflammatory diseases. Our previous study demonstrated that the PvHE attenuated the sickness behavior in mice, supporting the popular use of flowers of Pyrostegia venusta as treatment for the general symptoms of flu and cold (Veloso et al., 2010). However, its pharmacological actions have not been completely investigated to date. The present study demonstrated that the hydroethanolic extract of the flowers of Pyrostegia venusta display antinociceptive and anti-inflammatory properties. Because the extract did not produce any mortality in mice even at a dose of $5 \mathrm{~g} / \mathrm{kg}$, it may be considered relatively safe.
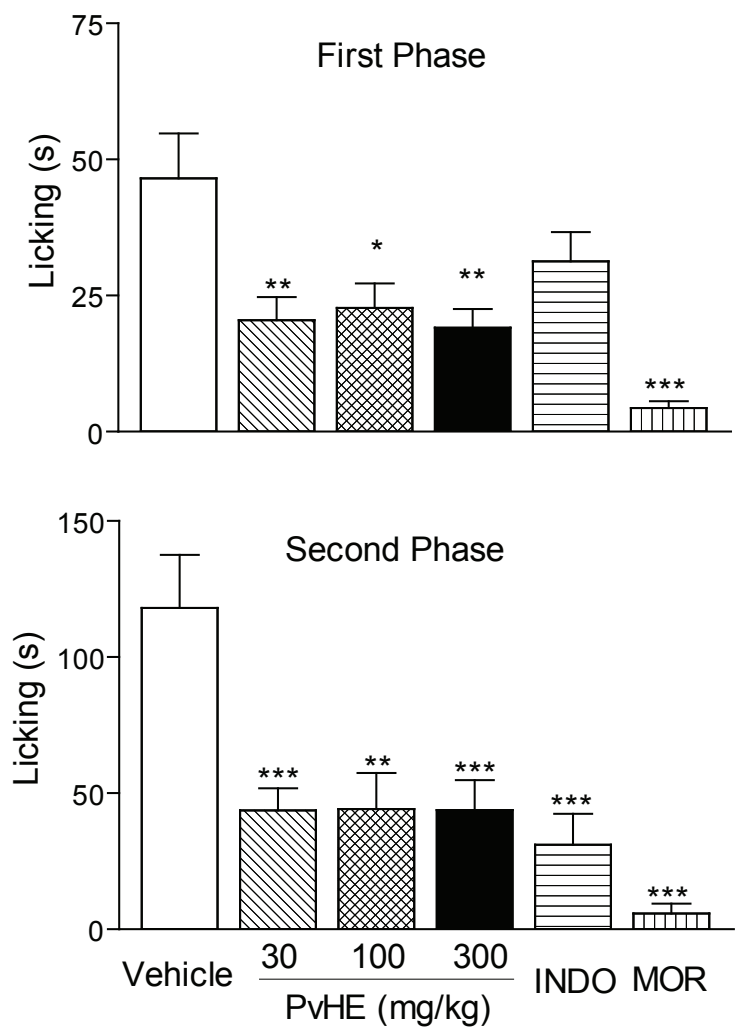

Figure 4. Effects of the hydroethanolic extract from Pyrostegia venusta flowers (PvHE) given by the oral route on the formalin test in mice. Animals were pretreated orally with the vehicle, PvHE (30, 100, and $300 \mathrm{mg} / \mathrm{kg}$ ), indomethacin (INDO; $10 \mathrm{mg} /$ $\mathrm{kg}$ ) or morphine (MOR; $1 \mathrm{mg} / \mathrm{kg}$ ) prior to formalin. The total time spent licking the hindpaw was measured in the first and second phases after intraplantar injection of formalin. Each column represents the mean with S.E.M. for eight mice. The asterisks denote the significance levels when compared with the control group: ${ }^{*} p<0.05 ; * * p<0.01 ; * * * p<0.001$.

In this study, the anti-inflammatory activity of the hydroethanolic extract from the flowers of Pyrostegia venusta were evaluated using the carrageenan-induced mice paw edema and peritonitis induced by LPS. In mice, the inflammatory response induced by carrageenan is characterized by a biphasic response (Vinegar et al., 1969). Marked edema formation resulting from a rapid production of several inflammatory mediators, such as histamine, serotonin and bradykinin, is observed in the first-phase. The second-phase is characterized by the release of prostaglandins and nitric oxide with a peak at $3 \mathrm{~h}$, produced by inducible isoforms of COX (COX-2) and nitric oxide synthase (iNOS), respectively (Seibert et al., 1994). Oral administration of the PvHE suppressed the edematous response in a dose-dependent manner $3 \mathrm{~h}$ after the carrageenan injection. The inhibitory effect of the $\mathrm{PvHE}$ on the carrageenan-induced inflammation in mice may be due to the inhibition of cyclooxygenase (Morris, 2003) because its effect can be compared to that caused by indomethacin. In another model of acute inflammation (peritonitis induced by lipopolysaccharide), the PvHE significantly reduced the leukocyte migration to the peritoneal cavity induced by lipopolysaccharides.

This work shows that the PvHE p.o. produces significant antinociception according to the assessment of the abdominal writhes elicited by acetic acid and the formalin test in mice. The PvHE was shown to possess antinociceptive activity to the abdominal writhes elicited by acetic acid. Pretreatment with the PvHE (100 and $300 \mathrm{mg} / \mathrm{kg}$ ) reduced the number of acetic acid-induced writhes in mice. This model, which is a visceral pain model, releases arachidonic acid via cyclo-oxygenase (COX); prostaglandins biosynthesis plays a notably important role in the nociceptive mechanism (Duarte et al., 1988). The results of the present study indicate that the analgesic effect of the PvHE may possibly be triggered by the inhibition of the synthesis or action of prostaglandin. The PvHE was found to be effective in both phases of formalin response. The early phase, named the non-inflammatory pain, is a result of the direct stimulation of nociceptors and reflects centrallymediated pain; the late phase, named the inflammatory pain, is caused by local inflammation with a release of inflammatory and hyperalgesic mediators (Hunskaar \& Hole, 1987). In this study, administration of the PvHE induced antinociceptive activities in both the early and late phases of the formalin test. The first phase is sensitive to drugs that interact with opioid system and the second phase is inhibited by nonsteroidal anti-inflammatory drugs. Drugs that act primarily as central analgesics inhibit both phases while peripherally acting drugs inhibit only the second phase (Rosland et al., 1990). In the present study, PvHE produced antinociception in both the early and late phases of formalin test. Considering the inhibitory property of PvHE on the first phase of formalin, is 
presumed that its possible antinociceptive activity is due a possible central action since its effect could be compared to that caused by morphine. Moreover, the antinociceptive effect of the PvHE in the second phase is due to its possible anti-inflammatory action, inhibiting the release of the inflammatory mediators. The possible nonspecific action of the muscle relaxants or the sedative effects was discarded, as tested on the open-field apparatus. This result corroborates the antiinflammatory and antinociceptive effect of the PvHE suggested by the nociceptive tests.

In previous studies, $\beta$-sitosterol, $n$-hentriacontane, $\quad$ acacetin-7-O- $\beta$-glucopyranoside and meso-inositol were identified (Dubey \& Misra, 1976). The anti-inflammatory activities of $\beta$-sitosterol and acacetin were demonstrated (Gupta et al., 1980; Shen et al., 2010). The anti-inflammatory activities of $\beta$-sitosterol isolated from the Cyperus rotundus, have shown carrageenan-induced edema in rats. $\beta$-sitosterol is found to possess potent anti-inflammatory activities, similar to that of hydrocortisone, when administered intraperitoneally (Gupta et al., 1980). Others studies have demonstrated that acacetin inhibits the induction of nitric oxide synthase (NOS) and cyclooxygenase-2 $(\mathrm{COX}-2)$ in macrophages that are activated with LPS by inhibiting the transcriptional activation (Pan et al., 2006; Shen et al., 2010). LPS produces proinflammatory cytokines which provokes a number of neuropsychological symptoms collectively referred to sickness behavior (Dantzer 2009; de Paiva et al., 2010). In addition, Veloso et al. (2010) observed that the hydroethanolic extract from flowers of Pyrostegia venusta attenuated the depressive-like and exploratory behaviors induced by LPS, suggesting that the PvHE inhibited the imune and inflammatory responses.

The precise mechanisms that are involved in the production of the anti-nociceptive and antiinflammatory responses of the Pyrostegia venusta extract are not completely understood, but they may be caused by the presence of flavonoid acacetin-7$O$-glycopyranoside identified by Veloso et al. (2010). The presence of flavonoids and phenolic compounds has been associated with various degrees of antiinflammatory and analgesic activities (Garcia-Leme, 2008).

Finally, the obtained results point out the potential of Pyrostegia venusta extract for the pharmacological control of pain and inflammatory processes. This study has shown that the hydroethanolic extract of the flowers of Pyrostegia venusta possess significant antinociceptive and anti-inflammatory effects in laboratory animals. Moreover, the results support the traditional use of this plant in some inflammatory conditions.

\section{Acknowledgments}

This work was supported by Fundação de Amparo a Pesquisa do Estado de Minas Gerais, Brazil, Grants \# APQ-1272-08 and \# APQ-2887-09. We thank Marina de Fátima Venâncio and José dos Reis Pereira for their excellent technical assistance.

\section{References}

Archer J 1973. Tests for emotionality in rats and mice: a review. Anim Behav 21: 205-235.

Blatt CTT, Santos MD, Salatino A 1998. Flavonoids of Bignoniaceae from "cerrado" and their possible taxonomic significance. Plant Syst Evol 210: 289292.

Cardozo NP, Parreira MC, Alves PL, Bianco S 2009. Foliar área estimate of two sugarcane-infesting weeds using leaf blade linear dimensions. Planta Daninha 27: 683-687.

Cunha FQ, Souza GE, Souza CA, Cerqueira BC, Ferreira $\mathrm{SH}$ 1989. In-vivo blockage of neutrophil migration by LPS is mimicked by a factor released from LPSstimulated macrophages. Brit J Exp Pathol 70: 1-8.

Dantzer R 2009. Cytokine, Sickness Behavior and Depression. Immunol Allergy Clin 29: 247-264.

De PaivaVN, Lima SNP, Fernandes MM, Soncini R, Andrade CA, Giusti-Paiva, A 2010. Prostaglandins mediate depressive-like behaviour induced by endotoxin in mice. Behav Brain Res 215: 146-151.

Duarte ID, Nakamura M, Ferreira SH 1988. Participation of the sympathetic system in acetic acid-induced writhing in mice. Braz J Med Biol Res 21: 341-343.

Dubey R, Misra KJ 1976. Chemical components of Pyrostegia venusta Xowers. J Indian Chem Soc 53: 378.

Emmanuel EI, Peter AA, Chukwuemeka SN 2010. Anticonvulsant Activity of Ethanol Leaf Extract of Spathodea campanulata P. Beauv (Bignoniaceae). $J$ Med Food 13: 827-833.

Ferreira DT, Alvares PS, Houghton PJ, Braz-Filho R 2000. Chemical constituents from roots of Pyrostegia venusta and considerations about its medicinal importance. Quim Nova 23: 42-46.

Folin C, Ciocalteu V 1927. Tyrosine and tryptophan determination in proteins. J Biol Chem 73: 627-650.

Gupta MB, Nath R, Srivastava N, Shanker K, Kishor K, Bhargava KP 1980. Anti-inflammatory and antipyretic activities of beta-sitosterol. Planta Med 39: 157-163.

Garcia-Leme J, Nakamura L, Leite MP, Rocha e Silva M 1973. Pharmacological analysis of the acute inflammation process induced in rat's paw by local injection of carrageenan and heating. Br J Pharmacol 64: 91-98.

Harbone JB 1967. Comparative biochemistry of the flavonoids. VI. Flavonoid patterns in the Bignoniaceae and Gesneriaceae. Phytochemistry 6: 1646-1651. 
Hunskaar S, Hole K 1987. The formalin test in mice: dissociation between inflammatory and non inflammatory pain. Pain 30: 103-114.

Koster R, Anderson M, De Beer EJ 1959. Acetic acid analgesic screening. Fed Proc 18: 418-420.

Morris CJ 2003. Carrageenan-induced paw edema in the rat and mouse. Methods Mol Cell Biol 225: 115-121.

Pan MH, Lai CS, Wang YJ, Ho CT 2006. Acacetin suppressed LPS-induced up expression of iNOS and COX-2 in murine macrophages and TPA-induced tumor promotion in mice. Biochem Pharmacol 72: 12931303.

Pool A 2008. A review of the genus Pyrostegia (Bignoniaceae). Ann Mo Bo Gard 95: 495-510.

Rosland JH, Tjolsen A, Maehle B, Hole DK 1990. The formalin test in mice. Effect of the formalin concentration. Pain 42: 235-242.

Santos AR, Calixto JB 1997. Further evidence for the involvement of tachykinin receptor subtypes in formalin and capsaicin models of pain in mice. Neuropeptides 31: 381-389.

Scalon SP, Vieira MC, Lima AA, Souza CM, Mussury RM 2008. Pregerminative treatments and incubation temperatures on the germination of "cipó-de-SãoJoão" [Pyrostegia venusta (Ker Gawl.) Miers] Bignoniaceae. Rev Bras Pl Med 10: 37-42.

Seibert K, Zhang Y, Leahy K, Hauser S, Masferrer J, Perkins W, Lee L, Isakson P 1994. Pharmacological and biochemical demonstration of the role of cyclooxygenase 2 in inflammation and pain. $P$ Natl Acad Sci USA 91: 12013-12017.
Shen KH, Hung SH, Yin LT, Huang CS, Chao CH, Liu CL, Shih YW 2010. Acacetin, a flavonoid,inhibits thein vasion and migration of human prostate cancer DU145 cells via inactivation of the p38 MAPK signaling pathway. Mol Cell Biol 333: 279-291.

Singleton VL, Orthofer R, Lamuela-Raventos RM 1999. Analysis of total phenol and other oxidation substrates and antioxidants by means of folin-ciocalteu reagente. Methods Enzimol 299: 152-178.

Veloso CC, Bitencourt AD, Cabral LDM, Franqui LS, Dias DF, dos Santos MH, Soncini R, Giusti-Paiva A 2010. Pyrostegia venusta attenuate the sickness behavior induced by lipopolysaccharide in mice. $J$ Ethnopharmacol 132: 355-358.

Vilela FC, Bitencourt AD, Cabral LD, Franqui LS, Soncini R, Giusti-Paiva A 2010. Anti-inflammatory and antipyretic effect of Sonchus oleraceus in rats. $J$ Ethnopharmacol 127: 737-741.

Vinegar R, Schreiber W, Hugo R 1969. Biphasic development of carrageenin edema in rats. J Pharmacol Exp Ther 166: 96-103.

\section{*Correspondence}

Alexandre Giusti-Paiva

Instituto de Ciências Biomédicas, Universidade Federal de Alfenas

Rua Gabriel Monteiro da Silva, 700,Centro, 37130-000, Alfenas - MG, Brasil

Tel: +55 $3532991303 ; 32991063$

giustipaiva@unifal-mg.edu.br 